\title{
Heat Flow and Geothermal Potential in the South-Central United States
}

\author{
Petru T. Negraru, ${ }^{1,3}$ David D. Blackwell, ${ }^{1}$ and Kamil Erkan ${ }^{2}$
}

\begin{abstract}
Received 1 February 2008; accepted 18 July 2008 Published online: 14 August 2008

Geothermal exploration is typically limited to high-grade hydrothermal reservoirs that are usually found in the western United States, yet large areas with subsurface temperatures above $150^{\circ} \mathrm{C}$ at economic drilling depths can be found east of the Rocky Mountains. The object of this paper is to present new heat flow data and to evaluate the geothermal potential of Texas and adjacent areas. The new data show that, west of the Ouachita Thrust Belt, the heat flow values are lower than east of the fault zone. Basement heat flow values for the Palo Duro and Fort Worth Basins are below $50 \mathrm{~mW} / \mathrm{m}^{2}$ while, in the frontal zone of the belt, they can exceed $60 \mathrm{~mW} / \mathrm{m}^{2}$. Further east, along the Balcones fault system the heat flow is in general higher than $55 \mathrm{~mW} / \mathrm{m}^{2}$. The eastern most heat flow sites are in Louisiana and they show very high heat flow (over $80 \mathrm{~mW} / \mathrm{m}^{2}$ ), which is associated with the apparently highly radioactive basement of the Sabine uplift. The geothermal resource in this area is large and diverse, and can be divided in high grade (temperature above $150^{\circ} \mathrm{C}$ ) convective systems, conductive based enhanced geothermal systems and geothermal/geopressured systems. One of the most attractive areas east of the cordillera extends from eastern Texas across Louisiana and Arkansas to western Mississippi. Here temperatures reach exploitation range at depths below $4 \mathrm{~km}$, and tapping such a resource from shut in hydrocarbon fields is relatively easy. The initial costs of the development can be greatly reduced if existing hydrocarbon infrastructure is used, and therefore using shut-in hydrocarbon fields for geothermal purposes should not be neglected.
\end{abstract}

KEY WORDS: Renewable energy, Texas heat flow, enhanced geothermal system, geopressured systems.

\section{INTRODUCTION}

Driven by ever-increasing dependence on imported oil, energy security will be one of the most important problems facing the United States in the next century. In addition, global warming emphasizes that renewable energy sources must become a

\footnotetext{
${ }^{1}$ Southern Methodist University, 750395, Dallas TX 75206, USA e-mail: pnegraru@smu.edu .

${ }^{2}$ School of Earth Sciences, The Ohio State University, 125 S. Oval Mall, 275 Mendenhall Laboratory, Columbus OH 43210, USA.

${ }^{3}$ To whom correspondence should be addressed; e-mail: pnegraru@smu.edu
}

larger portion of our energy supply. Among them geothermal energy plays an important role. Geothermal exploitation is usually associated with resources located in the western United States, where high temperatures may be encountered over large regional areas (Blackwell, Negraru, and Richards, 2007), but in general only high-grade (in excess of $150^{\circ} \mathrm{C}$ ) geothermal resources are exploited. Yet areas east of Rocky Mountains possess an important geothermal potential. This paper presents new heat flow data in Texas and discusses the available heat flow information in south-central United States east of the Rocky Mountains, as well as the implications for the geothermal resource of the Texas and adjoining areas. The geothermal 


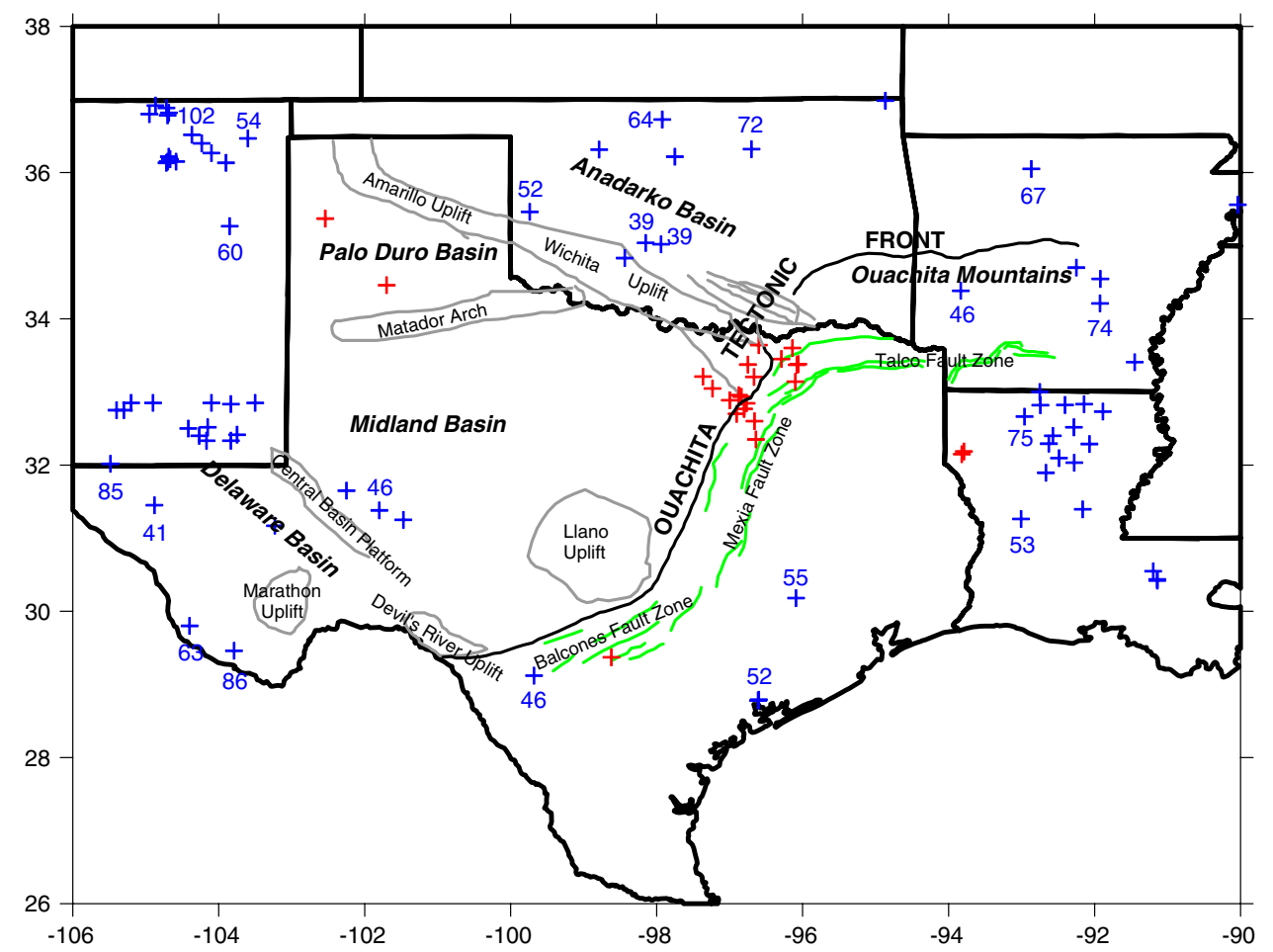

Figure 1. Location of published heat flow values (blue crosses) and generalized structure map of Texas, showing the position of basement uplifts and intervening basins. Also shown are the Balcones, Mexia and Talco Fault Zones. The wells used in this study are located in Palo Duro and Fort Worth Basins, Dallas area, Balcones, Mexia, and Talco Fault zones (red crosses). The numbers show the general regional heat flow values in $\mathrm{mW} / \mathrm{m}^{2}$.

resources in the north central third of the country are addressed in a companion study (W. D. Gosnold, personal communication, 2007). Our assessments overlap in Oklahoma and Kansas, but the approach described below is somewhat different.

Figure 1 shows the locations of the wells for which new heat flow values are reported in this paper. Most of them are located in north-central Texas, in an area extending from the Fort Worth Basin in the west, across the Ouachita Tectonic front, including the Dallas area, up to the Balcones Fault Zone in the east. Two wells are located in the Palo Duro Basin, and two others in northwestern Louisiana, a few miles east from the Texas border. Gradient information for one well in central Texas is also available (located within the Lackland Air Force Base). The current geologic setting is dominated by the Paleozoic Ouachita system, which has an approximate north-south orientation and splits the study area in two main parts. To the west Paleozoic sedimentary rocks with a thin cover of Mesozoic sediments overly undeformed basement rocks of Precambrian age belonging to the Texas
Craton. To the east, Paleozoic Ouachita rocks are overlain by Cretaceous sediments. Within the Ouachita system two tectonic provinces are recognized (Flawn and others, 1961). The first is a frontal zone bordering the Texas Craton where deformation was by flexure, and the second is an interior zone where shear deformation predominated (reactivated by the Balcones Fault zone). The nature of the basement beneath the Ouachita rocks is unknown.

In spite of the extensive drilling in the area, very few reliable heat flow data are available. Only in two relatively similar geologic areas have heat flow values been published. To the southwest of the Fort Worth Basin, a heat flow of $46 \mathrm{~mW} / \mathrm{m}^{2}$ was measured for the Midland Basin (Herrin and Clark, 1956) while southeast of the Ouachita front, in the Gulf Coast, Blackwell and others (1999) determined heat flow values of 52 and $55 \mathrm{~mW} / \mathrm{m}^{2}$ in two wells. They also used high resolution temperature-geophysical $\log$ correlations to obtain information about the thermal conductivity values of particular formations. A similar approach was employed for a number of wells in this study. 
Heat flow values as low as $39 \mathrm{~mW} / \mathrm{m}^{2}$ were reported north of our area, in southwest Oklahoma, associated with low heat production rocks (mafic complex) of the Wichita Uplift (Carter, 1993; Carter and others, 1998; Gallardo and Blackwell, 1999). This complex might affect the heat flow regime of the most northern wells in our study area.

The new data presented here are based on temperature logs that are characterized by a number of high resolution well-logs in the Fort Worth Basin (the first accurate heat flow values for the Fort Worth Basin), Palo Duro Basin and East Texas Basin. In addition, eight mostly high resolution welllogs were measured in the Dallas area, around the frontal zone of the Ouachita, and eight low resolution well-logs were made in the Mexia and Talco Fault zones. The purpose of this work is to understand the general temperature regime in the southwest and to assess the geothermal potential of the area.

\section{HEAT FLOW DETERMINATIONS}

\section{Dallas Area}

The Mobil New Exploration Ventures Farmers Branch \#1 (MNEV) was drilled on the Mobil Dallas Research campus in the spring of 1991. The hole was cored top to bottom because the purpose of the well was to evaluate drilling and testing techniques for hydrocarbon exploration using core-drilling equipment and "small" diameter wells. Extensive openhole logs were run on the well and the core samples were cataloged, videotaped, and gamma ray logged. Because of the extensive information available from the well and the fact that the well remained accessible for a long time, there were opportunities to carry out experiments and evaluations and develop techniques not possible in the typical exploration situation. For example, the well was thermally logged seven times following drilling as it approached thermal equilibrium allowing the detailed nature of the drilling effects and the recovery process to be documented (Fig. 2). This particular well is the only one for which thermal conductivity values for the upper Cretaceous rocks were measured on core samples from the actual well with thermal gradient data. The well penetrated a typical Cretaceous geologic section, starting with a very thin layer of the Upper Cretaceous Austin Chalk in outcrop (Fig. 3).

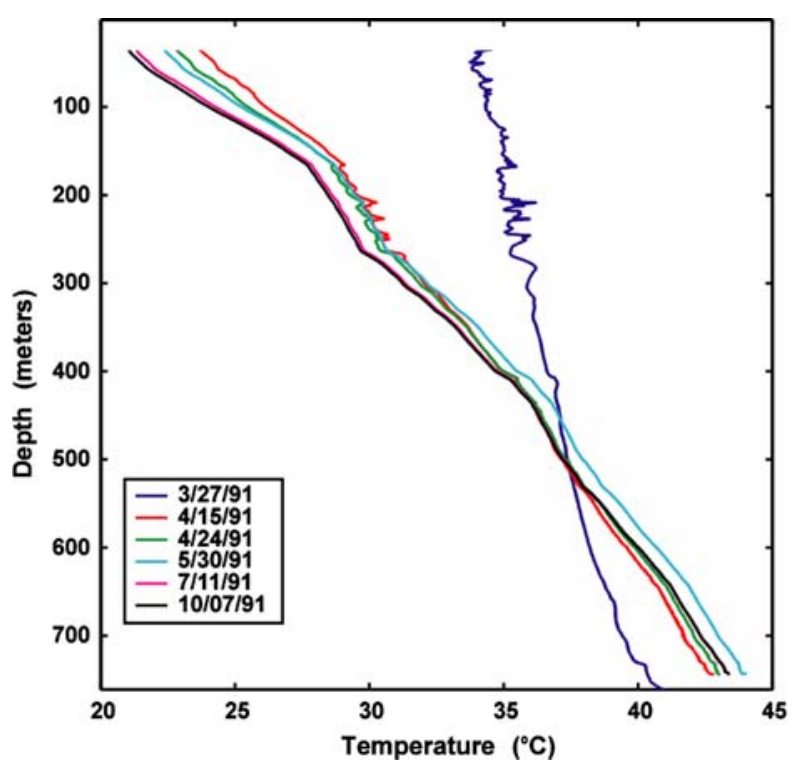

Figure 2. Repeated temperature depth curves for MNEV well. The first $\log$ about $1 \mathrm{~h}$ after completion of drilling (03/27/91) shows the characteristic cooling of the lower part of the well and the heating of the upper part of the well caused by drilling fluids. The last two logs (07/11/91 and 10/07/91) are in almost complete thermal equilibrium. The wiggles on the intermediate logs are related to fluid losses in the Woodbine Sandstone, which required the longest time to reach thermal equilibrium.

The entire MNEV well was logged for the first time on March 27th, 1991, following completion of circulation by only an hour or so. The log shows the characteristic heating of the upper part of the well and the cooling of the lower part of the well by the drilling process. The heating in the upper part of the hole on the log of March 27th is due to the longer period of circulation effect. This log also shows several spikes in the upper part of the well due to invasion of the formation by drilling fluid; these peaks are correlated with washout zones in the caliper log. Over time the well bore cools in the upper part and heats in the lower part as it approaches equilibrium. For the logs on and after April 15th, 1991 the dominant features are lithologically related gradient variations and the invasion of drilling fluid into the Woodbine Sandstone. As a result of the invasion, the Woodbine Sandstone required the longest time to reach thermal equilibrium.

The dependence of the thermal conductivity upon porosity, volume of shale, mineralogy, and temperature are discussed in Blackwell and Steele (1989). In general, conductivity determination is the main source of error in heat flow estimates because of lack of appropriate sampling. The various laboratory 

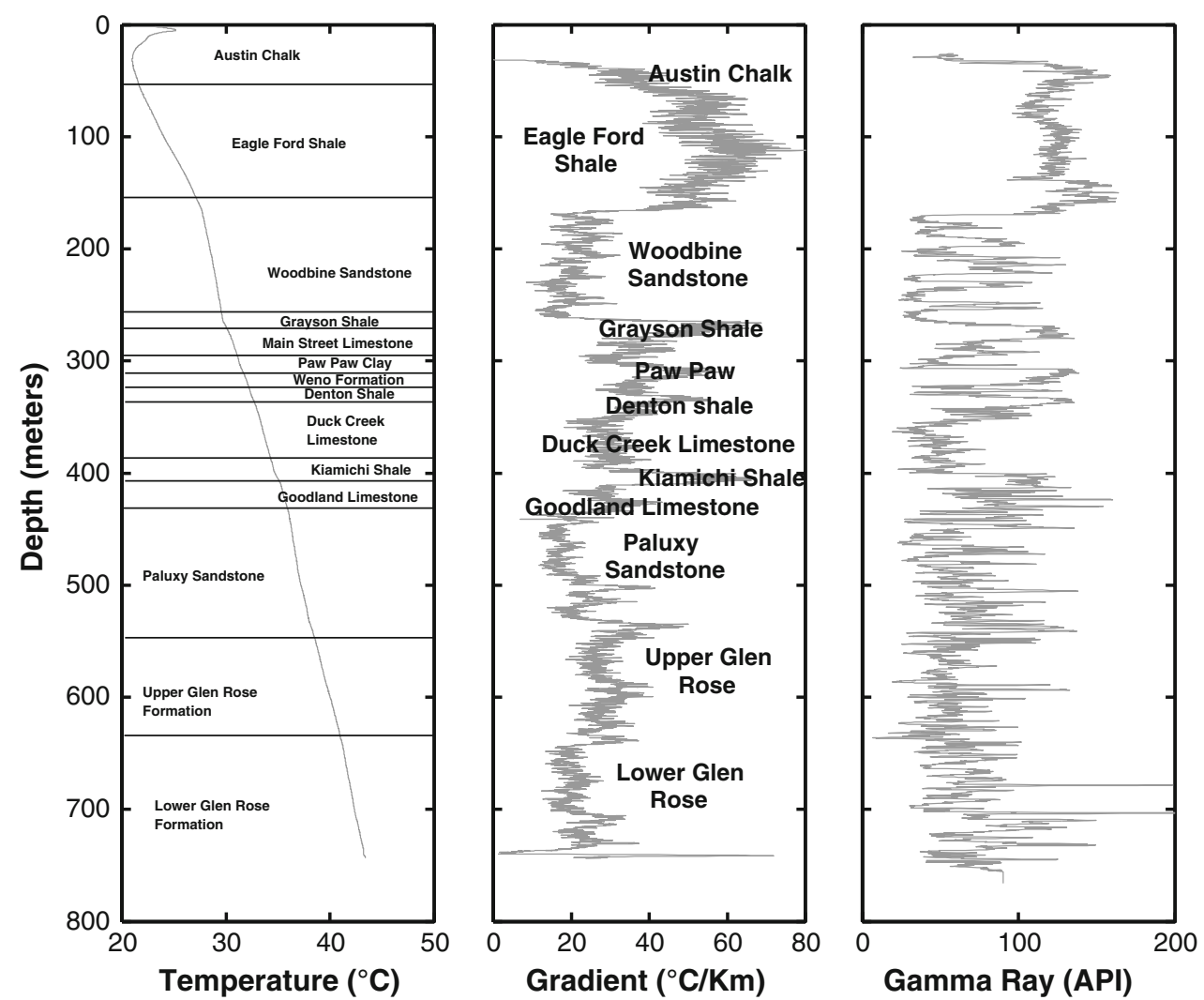

Figure 3. Temperature depth, temperature gradient, and natural gamma radiation log for the MNEV well. The main formations are identified on the gradient curve. The natural gamma radiation log was also used to delimitate the individual units.

techniques are discussed in detail by Gretener (1981) and Blackwell and Spafford (1987).

The approach was to calculate average thermal conductivities for the individual formations in MNEV, and then (by identifying the same formations in other wells using temperature gradient correlation) estimate heat flow values for all other wells in the Dallas area using the thermal conductivities from MNEV. Essentially, the MNEV was used to calibrate thermal conductivity for strata penetrated by the wells in the Dallas area: this process was possible because of the relatively simple layer-cake structure of the geology in the area and the relative lateral homogeneity of the Cretaceous units.

An indirect method for estimating the thermal conductivity makes use of well logs to determine lithology. If a complete log suite is available, then the lithology can be resolved and various mixing laws can be applied to obtain conductivity estimates (see Merkel, Maccary, and Chico, 1976; Brigaud, Chapman, and Le Douran, 1990; Doveton, Forster, and Merriam, 1997). Such an approach was employed for the wells in Fort Worth Basin and in the Louisiana continuation of the East Texas Basin.

In MNEV conductivities were measured on both dry and water saturated samples using the divided bar technique (Blackwell and Spafford, 1987). Shales are difficult to sample and characterize because of the tendency of the shale to disintegrate upon drying and because of the anisotropy of the clay particles. As a result literature values of the thermal conductivity of shales are typically $50-100 \%$ too high (Blackwell and Steele, 1989). Special effort was focused on the Eagle Ford Shale thermal conductivity because of the opportunity to sample material immediately after it was removed from the ground prior to desiccation. Thermal conductivity was measured on nine shale samples. In addition to the Eagle Ford Shale, other sampled formations were the Main Street Limestone, the Paluxy Sandstone, and the Upper and Lower Glen Rose Formation. The average values of thermal conductivities, as expected, are inversely related to the thermal gradients measured in the corresponding formations in that the shales 
have the lowest conductivity, but highest gradient, the limestones have intermediate conductivities and gradients, and the sandstones the highest thermal conductivity values but lowest thermal gradients.

The average heat flow for each interval was calculated and the gradients and thermal conductivity values for formations with enough representation of thermal conductivity samples were averaged. The variation in the calculated heat flow

Table 1. Calculated Thermal Conductivities for Formations in MNEV well

\begin{tabular}{lc}
\hline Formation & $\begin{array}{c}\text { Calculated average } \\
\text { thermal conductivity }\left(\mathrm{Wm}^{-1} \mathrm{~K}^{-1}\right)\end{array}$ \\
\hline Eagle Ford Shale & 1.13 \\
Woodbine Sand & 2.95 \\
Grayson Shale & 1.37 \\
Main Street Limestone & 2.05 \\
Paw Paw Clay & 1.25 \\
Weno Formation & 1.72 \\
Denton Shale & 1.58 \\
Duck Creek Limestone & 1.99 \\
Kiamichi Shale & 1.06 \\
Goodland Limestone & 2.10 \\
Paluxy Sandstone & 3.42 \\
Glenrose Formation & 2.05 \\
\hline
\end{tabular}

values is random with depth and varies from 41 to $70 \mathrm{~mW} / \mathrm{m}^{2}$, with all but four of the interval calculations being within $10 \%$ of the mean value of $61 \pm 2 \mathrm{~mW} / \mathrm{m}^{2}$ (standard error) which is the best estimate of the heat flow for MNEV.

Assuming a vertical and constant heat flow of $61 \mathrm{~mW} / \mathrm{m}^{2}$, apparent in situ conductivities were determined for each individual formation by dividing the heat flow by the mean thermal gradients of each formation. These theoretical conductivities (Table 1) were used to obtain heat flow values for the other wells in the same area, and to build a thermal resistance model for the Bullard plots (see below) in the East Texas wells.

In the Dallas area temperature data are available for a number of other wells (Otis, SMU water well, Mobil Duncanville, Cadiz, Trigg, McKinney, and Gunter, Fig. 4). Although only generalized lithologic information was available, gradient correlation between MNEV and the other wells allowed identification of individual formations. Then using average conductivities values (determined for MNEV), heat flow values for these wells were computed.

The correlation is best illustrated between the SMU water well and MNEV, about $10 \mathrm{~km}$ apart (Fig. 4). Individual formations can be easily identified by their characteristic gradient patterns. For the
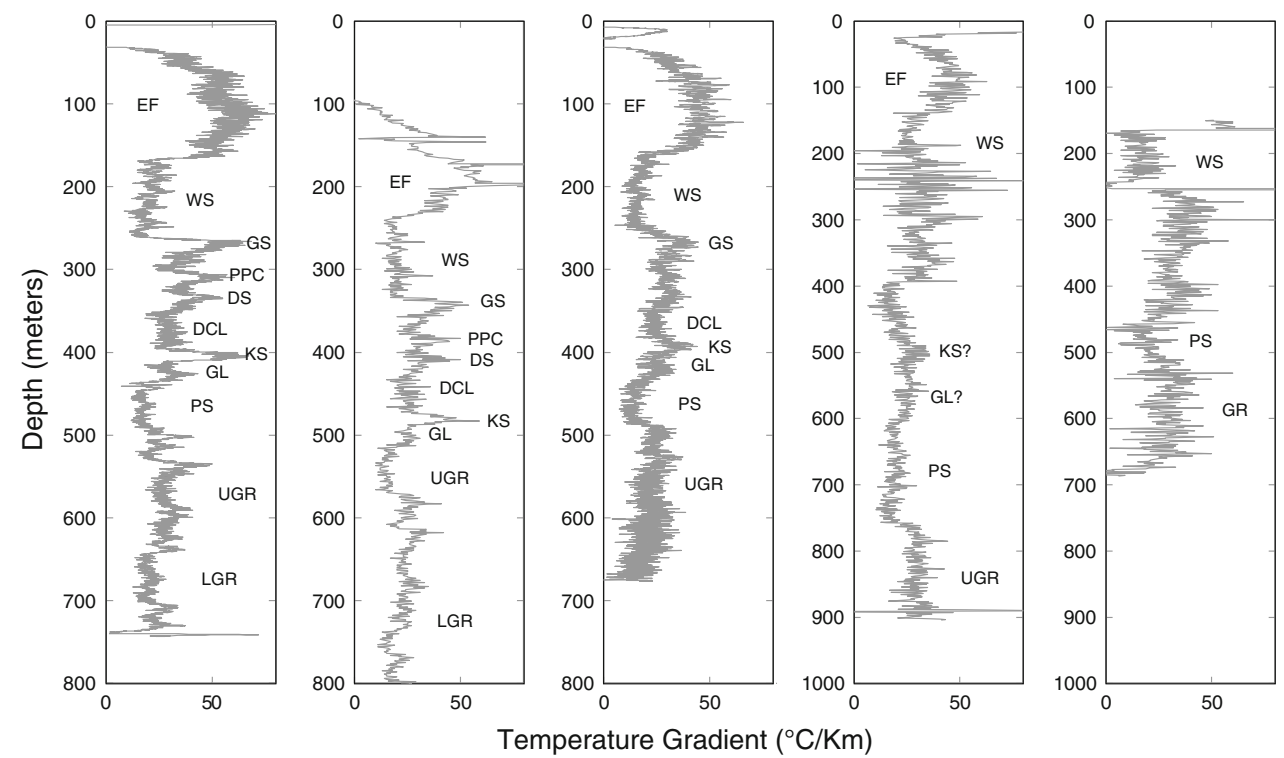

Figure 4. Temperature gradient correlation for deep wells in Dallas area with high-resolution gradient data. From left to right the wells are: MNEV, SMU, Mobil Duncanville, Otis, and Cadiz. The letters indicate formations: EF_-Eagle Ford Shale, WS—Woodbine Sandstone, GS—Grayson Shale, PPC_Paw Paw Clay, DS—Denton Shale, DCL-Duck Creek Limestone, GL-Goodland Limestone, PS—Paluxy Sandstone, UGR-Upper Glen Rose, LGR_-Lower Glen Rose. 
Mobil Duncanville well the thermal signatures for the Grayson and Kiamichi shale are more attenuated than for MNEV and SMU, probably because of a change in facies (less clay in the section). For this reason, the gradients obtained for these formations were removed from calculation. For the Otis well heat flow values were obtained from the gradients of Eagle Ford, Paluxy, and Glen Rose formations. The section between 400 and $600 \mathrm{~m}$ corresponds to 260$430 \mathrm{~m}$ in MNEV, which contains all the formations from the Grayson Shale to the Goodland Limestone. An average gradient of $32.2^{\circ} \mathrm{C} / \mathrm{km}$ and an average conductivity value of $1.55 \mathrm{~W} / \mathrm{m} / \mathrm{K}$ were used for this section to compute the interval heat flow. The gradient obtained for the Woodbine Sandstone was not used because of the obvious departure from equilibrium. A similar approach was used for Cadiz well, averaging over the same formations between 260 and $460 \mathrm{~m}$. In addition, heat flow values were obtained from the Woodbine, Paluxy, and Glen Rose formations.

The Trigg well was logged in the 1960s at $5 \mathrm{~m}$ intervals, but formation contacts are known and it was possible to correlate the gradient with MNEV and obtain accurate gradient measurements for particular formations. The Gunter and McKinney are relatively shallow wells, which penetrate Eagle Ford Shale and Austin Chalk, respectively. Gradients were used in the Eagle Ford Shale in the bottom part of the well and give a heat flow value for the McKinney well of $51 \mathrm{~mW} / \mathrm{m}^{2}$. The Gunther well is shallower and was logged at $5 \mathrm{~m}$ intervals. This well was used in a climate study, but no heat flow value was published for it (Gosnold, Todhunter, and Schmidt, 1997). The measured gradient is $40^{\circ} \mathrm{C} / \mathrm{km}$ for Eagle Ford Shale, and the calculated heat flow value is $44 \mathrm{~mW} / \mathrm{m}^{2}$. With the exception of heat flow in Mobil Duncanville and Gunter below $50 \mathrm{~mW} / \mathrm{m}^{2}$, all the other wells have heat flow values in the $50-60 \mathrm{~mW} / \mathrm{m}^{2}$ range (Table 2 ).

\section{North East Texas Wells}

Bullard plots were used to compute heat flow values for several wells in northeast Texas. The Bullard plot is based on the concept of thermal resistance, that is a measure of how effectively the flow of heat is retarded (Beardsmore and Cull, 2001). The thermal resistance, $R$, is defined as the integral of the reciprocal of thermal conductivity $\lambda$, over the depth range, $z$ :
Table 2. Summary of Results of the Heat Flow Calculations Used in This Study

\begin{tabular}{|c|c|c|c|}
\hline Well name & $\begin{array}{c}\text { Longitude } \\
\text { (decimal } \\
\text { degrees) }\end{array}$ & $\begin{array}{l}\text { Latitude } \\
\text { (decimal } \\
\text { degrees) }\end{array}$ & $\begin{array}{c}\text { Heat } \\
\text { flow } \\
\left(\mathrm{mW} / \mathrm{m}^{2}\right)\end{array}$ \\
\hline MNEV & -96.8386 & 32.9345 & $61 \pm 2$ \\
\hline Otis & -96.873 & 32.9553 & $52 \pm 11$ \\
\hline Cadiz & -96.8021 & 32.768 & $56 \pm 9$ \\
\hline SMU & -96.7681 & 32.8438 & $53 \pm 4$ \\
\hline Mobil Duncanville. & -96.9038 & 32.6997 & $48 \pm 2$ \\
\hline Trigg & -96.9983 & 32.8852 & $61 \pm 13$ \\
\hline Bonham & -96.14 & 33.6 & $56 \pm 6$ \\
\hline Aswastika Co. Owens \#1 & -96.29 & 33.45 & $43 \pm 6$ \\
\hline Ferris Brick & -96.66 & 32.6 & $51 \pm 6$ \\
\hline Ennis & -96.64 & 32.35 & $52 \pm 6$ \\
\hline Wolfe City & -96.06 & 33.38 & $57 \pm 6$ \\
\hline Kimbell & -96.08 & 33.37 & $58 \pm 6$ \\
\hline Sherman & -96.6 & 33.64 & $41 \pm 6$ \\
\hline Greenville & -96.1 & 33.14 & $53 \pm 6$ \\
\hline Smith \#1 & -97.23511 & 33.04602 & $48 \pm 5$ \\
\hline Union Central \#2 & -97.36411 & 33.2095 & $48 \pm 5$ \\
\hline Mckinney & -96.6666 & 33.205 & $51 \pm 5$ \\
\hline Gunter & -96.75 & 33.374 & $44 \pm 5$ \\
\hline Mansfield \#1 & -101.7 & 34.46 & $52 \pm 5$ \\
\hline Zeeck \#1 & -102.54 & 35.37 & $50 \pm 5$ \\
\hline Mosley \#1 & -93.79 & 32.185 & $82 \pm 6$ \\
\hline Haynes \#1 & -93.8189 & 32.1483 & $82 \pm 6$ \\
\hline Lackland & -98.62 & 29.37 & 34 \\
\hline
\end{tabular}

$$
\begin{gathered}
R=\int \frac{1}{\lambda} \partial z \\
Q_{d}=\lambda_{d}\left(\frac{\partial T}{\partial z}\right)_{d} \\
Q_{d}=\left(\frac{\lambda}{\partial z}\right)_{d} \partial T=\left(\frac{1}{\partial R}\right)_{d} \partial T=\left(\frac{\partial T}{\partial R}\right)_{d}
\end{gathered}
$$

The last equation states that the heat flow at any depth, $d$, is equal to the gradient of temperature with respect to the thermal resistance. A plot of temperature against thermal resistance is known as a Bullard plot (after Bullard, 1939).

In 1929-1930, a study was carried out by the American Petroleum Institute to determine the temperature gradients in wells throughout the entire area underlain by the Woodbine Sandstone. The temperature was measured at an interval of 75 or $150 \mathrm{~m}$ (Plummer and Sargent, 1931) with maximum reading mercury thermometers. Although over 300 wells were used in the study, temperature data were published only for 40 wells. In this study, we did not include in the calculations temperature data that were collected within a few days of the well being pumped or data from wells in areas where the temperature field was disturbed by high thermalconductivity salt domes, a common feature in the East Texas basin. 


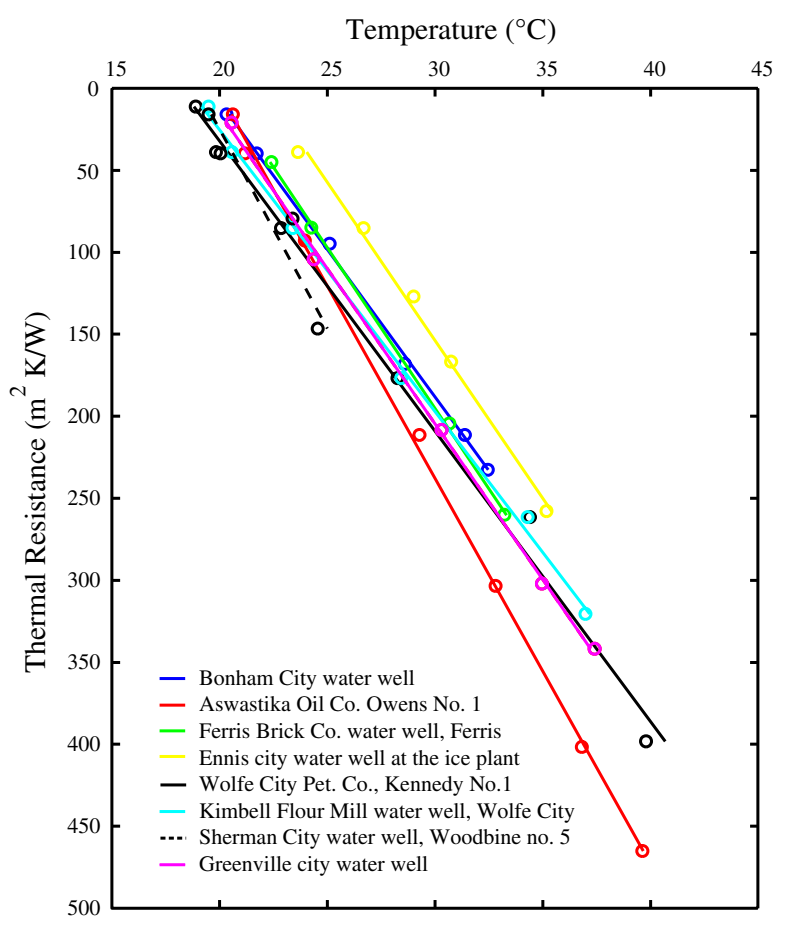

Fig. 5. Bullard plots for data from wells in north-east Texas. Most wells have heat flow values between 50 and $59 \mathrm{~mW} / \mathrm{m}^{2}$. The exceptions are lower values for the Sherman city water well and Aswastika Oil. Co. Owens no. 1.

A layered geological model was chosen, and conductivities were assigned for each individual layer. The formation conductivities used were those measured in the MNEV well. For the upper Cretaceous sediments that belong to the Navarro or Taylor groups (marls and shaly marls), where measured conductivities were not available to us, a conductivity of $1.6 \mathrm{~W} / \mathrm{m} / \mathrm{K}$ was used. Geological maps with Eagle Ford and Woodbine thickness (isopach), and structure maps that show the top of Paluxy, Woodbine and Eagle Ford formations, were used to constrain formation thickness in our models (Beall, 1964; Olivier, 1971; Owen, 1979; Surles, 1987). For each temperature point, the thermal resistance was computed from the individual layers:

$$
R=\sum_{i}\left(\frac{\Delta z_{i}}{\lambda_{i}}\right)
$$

where $\Delta z_{i}$ and $\lambda_{i}$ represent the $i$ th layer thickness and thermal conductivity, respectively. A Bullard plot was then created (Fig. 5) and a line was fit through the data (L1 norm). The slope of the line (heat flow) was computed for each well.

Most of the wells have heat flow values between 50 and $59 \mathrm{~mW} / \mathrm{m}^{2}$. The exceptions are Sherman city water well $\left(41 \pm 6 \mathrm{~mW} / \mathrm{m}^{2}\right)$ and Aswastika Oil. Co. Owens No. $1\left(43 \pm 6 \mathrm{~mW} / \mathrm{m}^{2}\right)$, both in the northern part of the area. Towards the east in the Talco fault zone, heat flow consistently exceeds $55 \mathrm{~mW} / \mathrm{m}^{2}$ (Table 2).

\section{Palo Duro Basin}

Detailed temperature data were available from two wells drilled by Stone and Webster Engineering Corporation (Stone and Webster Eng. Corp. Mansfield No. 1 and Zeeck No. 1) in the Palo Duro Basin. These wells were drilled as part of an investigation appraising the suitability of sites in the Texas Panhandle for possible nuclear waste disposal facility.

The Palo Duro Basin is an asymmetric, relatively shallow, intracratonic basin in the southern Texas Panhandle, filled mostly by Mississippian, Pennsylvanian, and Permian sedimentary rocks. The present study was concentrated on the salt-bearing rocks from the upper Permian (Ochoa, Guadelupe, and Leonard series). The Permian section includes limestone, sandstone, red beds, and evaporates (salt and anhydrite). Both wells bottom in the upper Pennsylvanian Cisco shale.

The gradient data show that the upper parts of the wells are not in complete thermal equilibrium, to a depth of approximately $700 \mathrm{~m}$ (Fig. 6). The higher gradient for the first $200 \mathrm{~m}$ in Mansfield \#1 is caused the thin blanket of Cenozoic deposits. A thick section of salt, evaporates, shale, sand, with some dolomite occurs from around 230 to $1030 \mathrm{~m}$. This section correlates with a section between about 700 and $1700 \mathrm{~m}$ in the Zeeck \#1 well. The upper boundary of this section (in Zeeck \#1) cannot be precisely determined due to noise in the gradient data. This thermal noise is residual drilling effects. The large excursions of the gradient peaks in the depth range 780-1100 m are a reflection of the complicated geology. In general, as a well approaches equilibrium, different sections of the well reach equilibrium at different times, depending of the physical properties of the rocks. It is also possible that the higher gradients are thin sandstone sections that require a larger time to approach equilibrium than shales because of fluid invasion into the sandstone during drilling.

Below $1030 \mathrm{~m}$ in Mansfield $\# 1$ and $1700 \mathrm{~m}$ in Zeeck \#1, which is the boundary between Permian and Pennsylvanian rocks, both wells have the same gradient characteristics. However, the gradient characteristics in the Pennsylvanian Cisco shale 

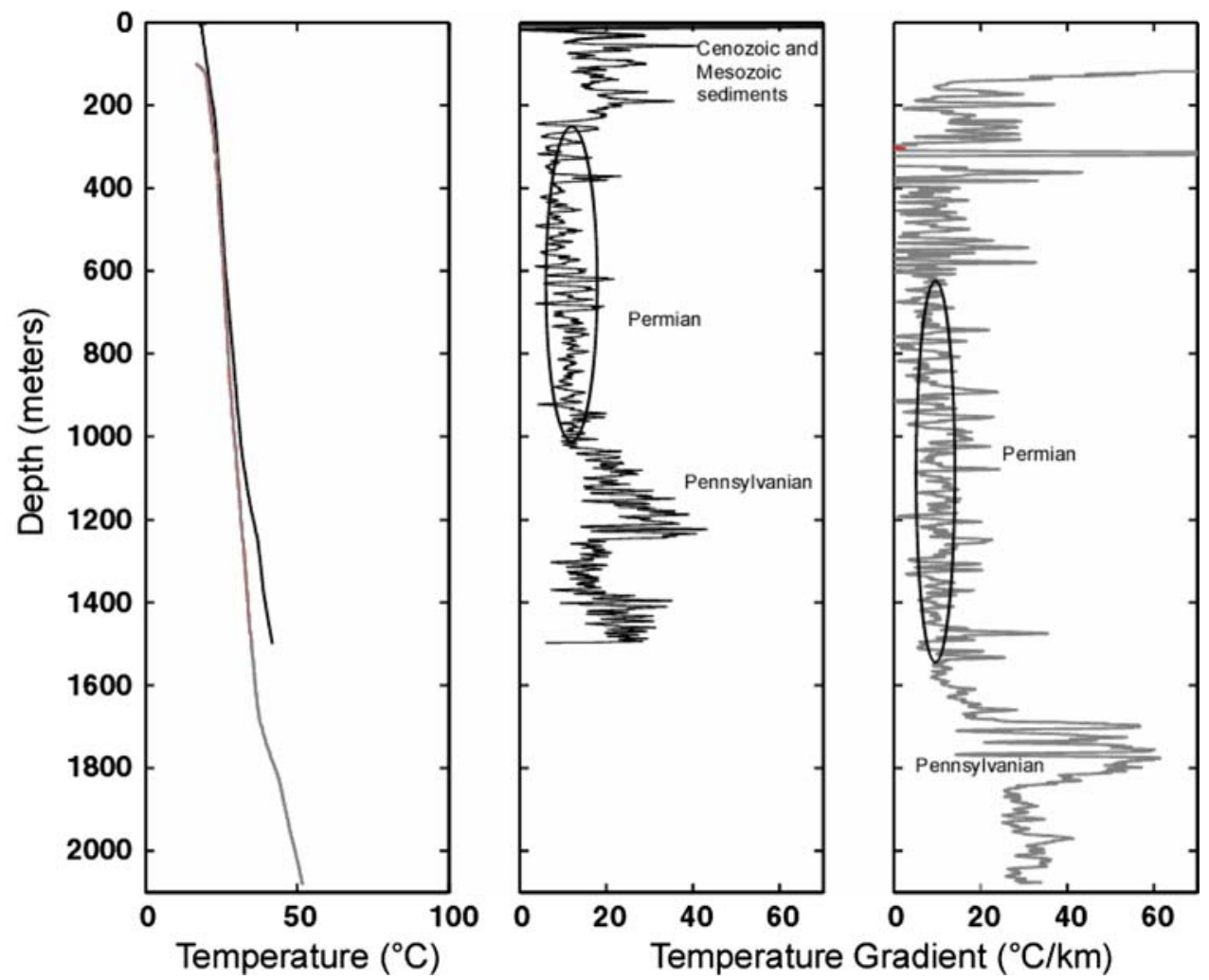

Fig. 6. Temperature/depth and gradient curves for Mansfield \#1 (gray) and Zeeck \#1 (black). The ellipses mark the intervals used to compute heat flow.

(1100-1250 $\mathrm{m}$ in Mansfield, and $1700-1850 \mathrm{~m}$ in Zeeck) are quite different. This difference could be explained by a transient effect in the Zeeck well, or by gas content in the shale, lowering the thermal conductivity and thereby increasing the gradient in the Zeeck well. The argument supporting high gas content is that, as a well approaches equilibrium, it reaches equilibrium from the bottom up. Thus if a well is not entirely in equilibrium it is expected that these sections will be in the upper part of the well unless affected by fluid flow in the formation. Below about $1250 \mathrm{~m}$ in Mansfield and $1850 \mathrm{~m}$ in Zeeck, there is a decrease in gradient. In Zeeck this decrease corresponds to a change in facies from shale to limestone and dolomite. The mud $\log$ for this depth also shows the presence of a relatively clean limestone. For Mansfield, the upper approximately $150 \mathrm{~m}$ (1250$1400 \mathrm{~m}$ ) is sandstone, followed by some limestone. Thus, the high gradient in the Pennsylvanian in the Zeeck well does not appear to have a transient source.

The most reliable heat flow estimate for the two wells is for the salt section. The average gradient for Vega (Mansfield \#1) for the interval $200-1000 \mathrm{~m}$ is $11.1^{\circ} \mathrm{C} / \mathrm{km}$ and for Zeeck the average gradient is $10.7^{\circ} \mathrm{C} / \mathrm{km}$. Lithologically this section contains chaotic mudstone and salt (Gustavson and others, 1981). Published conductivity values for the adjacent Anadarko basin (Oklahoma) were used to determine the heat flow. Using a conductivity estimate of $4.65 \mathrm{~W} \mathrm{~m}^{-1} \mathrm{~K}^{-1}$ for the Permian section (Gallardo and Blackwell, 1999) the heat flow values for these wells are $51.6 \mathrm{~mW} / \mathrm{m}^{2}$ (for Mansfield) and $49.8 \mathrm{~mW} / \mathrm{m}^{2}$ (for Zeeck).

Herrin and Clark (1956) discussed the salt conductivity and concluded that the purity of salt does not have any effect on the thermal conductivity. The conductivity of salt and evaporate sections measured in Midland Basin ranges from 12.9 to $13.9 \mathrm{cal} / \mathrm{cm}^{2} \mathrm{~s}{ }^{\circ} \mathrm{C}\left(5.36-5.82 \mathrm{~W} \mathrm{~m}^{-1} \mathrm{~K}^{-1}\right)$. The reason for using a lower conductivity in the Palo Duro is that the salt appears in thin layers interbedded with red beds (mixture of sand and shale) that have a lower conductivity and can drastically lower the average conductivity value.

Heat flow values from Herrin and Clark (1956) in the adjacent Midland basin (Permian Basin) range from 0.9 to $1.3 \mathrm{cal} / \mathrm{cm}^{2} \mathrm{~s}\left(37.7-54.4 \mathrm{~mW} / \mathrm{m}^{2}\right)$, but the reliable measurements range from 1 to 

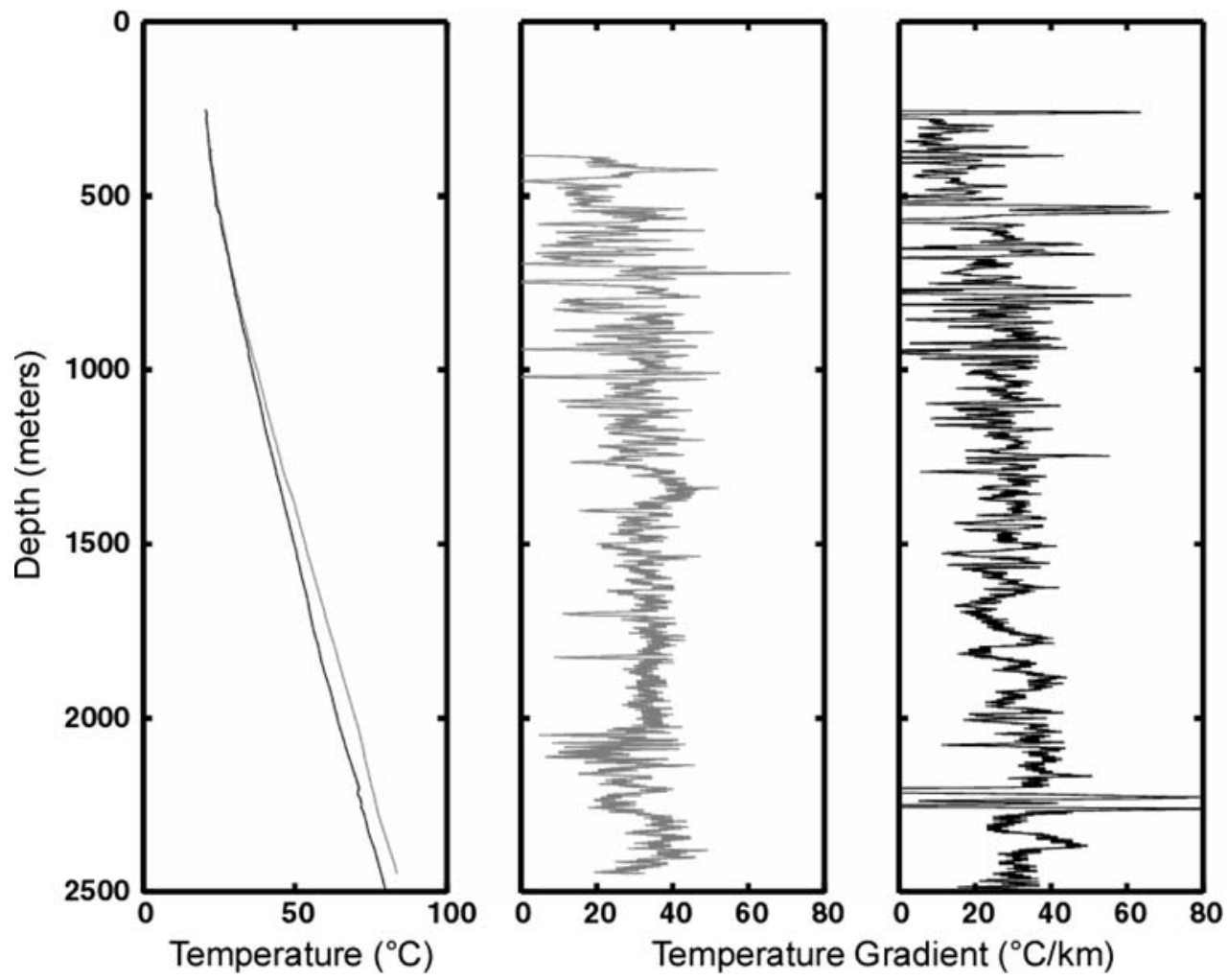

Fig. 7. Temperature and temperature gradient for the Fort Worth basin wells Smith \#1 (gray) and Union Central \#1 (black).

$1.2 \times 10^{-6} \mathrm{cal} / \mathrm{cm}^{2} \mathrm{~s}\left(41.8-50.2 \mathrm{~mW} / \mathrm{m}^{2}\right)$. These values are within the error range of the heat flow estimate for the Palo Duro Basin.

\section{Fort Worth Basin}

The Smith \#1 and Union Central \#1 were drilled on the northern edge of the Fort Worth Basin to assess the producing capabilities of the gas prone formations belonging to the Barnett Shale. A relatively complete set of logs indicates that the geologic section consists mainly of shales. The well logs were used to estimate the radiogenic heat of the sediments and to select homogeneous and thick layers to compute the heat flow.

The shallow part of the temperature $\log$ in Smith \#1 is not in thermal equilibrium and drilling effects are evident above $450 \mathrm{~m}$ (Fig. 7). They attenuate with depth and from about $900 \mathrm{~m}$ the temperature of the well is close to thermal equilibrium (see MNEV, Fig. 2). Exceptions are small disturbances in the $1650-1750 \mathrm{~m}$ depth interval probably caused by drilling fluid loss into porous sand layers, which in general require more time to reach thermal equilibrium (see Woodbine Sandstone section in MNEV, Fig. 2). To obtain a heatflow value, the gradient and the thermal conductivity for the thickest uniform layers were used: 945-975, $1160-1310$, and $1340-1645 \mathrm{~m}$. The average temperature gradients for the shale sections are between 31 and $33^{\circ} \mathrm{C} / \mathrm{km}$. Thus, the average heat flow for Smith $\# 1$ is $48.3 \mathrm{~mW} / \mathrm{m}^{2}$, using the Paleozoic shale conductivity $\left(1.5 \mathrm{~W} \mathrm{~m}^{-1} \mathrm{~K}^{-1}\right)$ from Gallardo and Blackwell (1999). The presence of gas might affect the thermal conductivity values below $2150 \mathrm{~m}$. The $\log$ for Union Central \#1 is further from equilibrium and is more disturbed, but the heat flow was estimated from the least disturbed sections of the log. All the gradient intervals in the lower part of the well have values of $28-34^{\circ} \mathrm{C} / \mathrm{km}$, so the estimated heat flow of $48 \mathrm{~mW} / \mathrm{m}^{2}$ is similar to Smith \#1.

\section{East Texas Basin}

Temperature logs from two wells, Mosley \#1 and Haynes \#1, drilled in the Louisiana continuation 

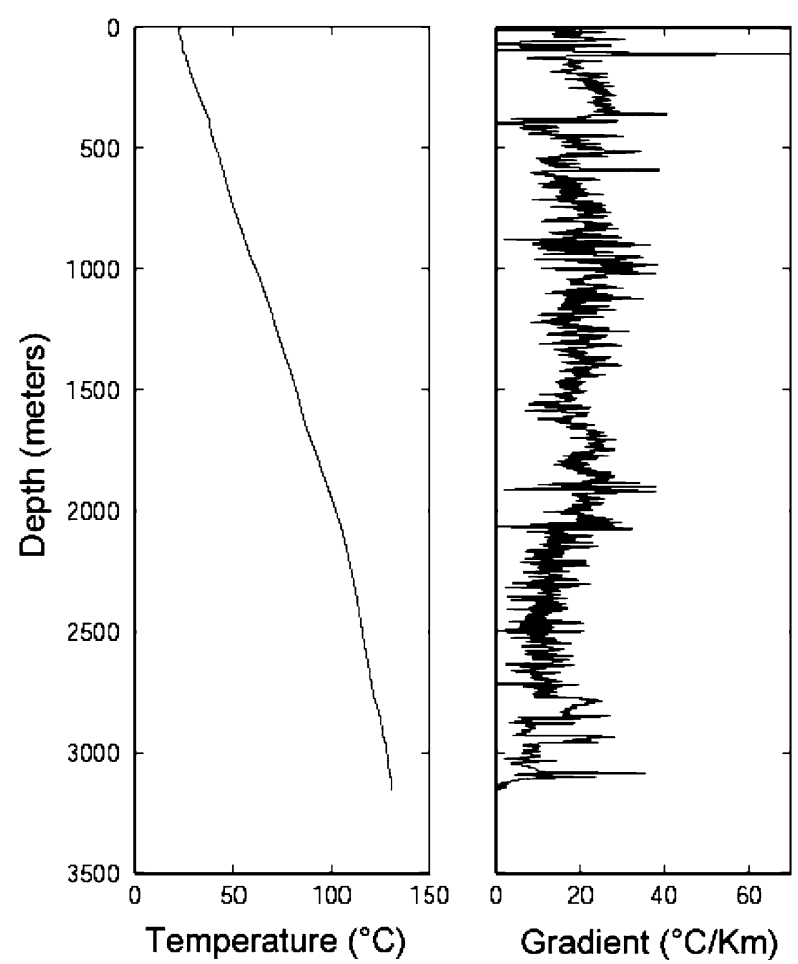

Fig. 8. Temperature (left) and temperature gradient for Mosley $\# 1$ well in Louisiana. The well Haynes \#1 has a similar distribution of temperature with depth.

of the East Texas Basin were acquired in the 1990. The wells are only $3 \mathrm{~km}$ apart, and their temperature depth curves, as expected, are very similar (Fig. 8).

Below a thin blanket of Cenozoic sediments the Mosley \#1 well penetrates Cretaceous sediments and bottoms in the Jurassic Cotton Valley group at depth of $3200 \mathrm{~m}$. Although no conductivity values are available for this well, a complete set of geophysical logs were used to determine the thermal characteristics.

Gamma ray, density, sonic, and neutron porosity logs were available from depths of $800 \mathrm{~m}$ to over $3000 \mathrm{~m}$. The relative percentages of different lithological units (shale, limestone, and sand) and their porosities were determined numerically using the simplex algorithm (Demongodin and others, 1991; Press and others, 1992). Once the lithology was determined, the thermal conductivity was computed for a water-saturated medium by weighting a geometric average conductivity model with volumetric percentage of each lithologic unit. Assuming a constant and vertical heat flow in the well, the thermal conductivity of each unit was determined such that the computed heat flow has the smallest standard deviation. These conductivities were $3.25,3.89$, and $5.12 \mathrm{~W} \mathrm{~m}^{-1} \mathrm{~K}^{-1}$ for shale, limestone and sandstone. All units have relatively high conductivities, close to the pure samples. The shales are particularly anomalous as most of the conductivities for shales are typically $1-1.6 \mathrm{~W} \mathrm{~m}^{-1} \mathrm{~K}^{-1}$. Although there are other shale indicators (e.g., SP log) only the natural gamma radiation log was available to us, and this was the primary tool in determining the shale content of the formations. However, siltstone could produce high gamma radiation and, due to the higher quartz content, could have significantly higher thermal conductivities. Therefore, we believe an important percentage of the interpreted shales are in fact siltstone. This is particularly true for the Hosston sand (top of Hosston is at $2072 \mathrm{~m}$ ), where the relative uniform low gradient values would indicate the presence of sandstone and siltstones rather than sandstone and shales. In the Cotton Valley Formation, the large gradient variations should indicate the presence of more marine shales with typical low conductivities. After performing the above analyses for several intervals, the best heat flow value for both the Mosley \#1 and Haynes \#1 wells was found to be $82 \pm 6 \mathrm{~mW} / \mathrm{m}^{2}$. The error is obtained from the standard deviation of the interval heat flow values.

\section{IMPLICATIONS FOR THE GEOTHERMAL POTENTIAL}

\section{Temperature and Heat Content}

Major components of the thermal resource potential are the temperature and the heat content of the rock. To compute the available heat content of the area, temperature at depth was calculated from the heat flow at depths from 3 to $10 \mathrm{~km}$ (Tester and others, 2006; Blackwell, Negraru, and Richards, 2007). The basic dataset from which the temperature was computed was the U.S. surface heat flow database. The calculation details are described in the appendix of Blackwell, Negraru, and Richards (2007). While drilling could exceed $10 \mathrm{~km}$, such depths are reached only in exceptional circumstances, and normally the 4-6 km depth range reflects more realistic maximum economic depths for drilling. Figure 9 shows the temperature maps for every kilometer from 3 to a depth of $8 \mathrm{~km}$ for the south-central part of the United States east of the Rocky Mountains. 

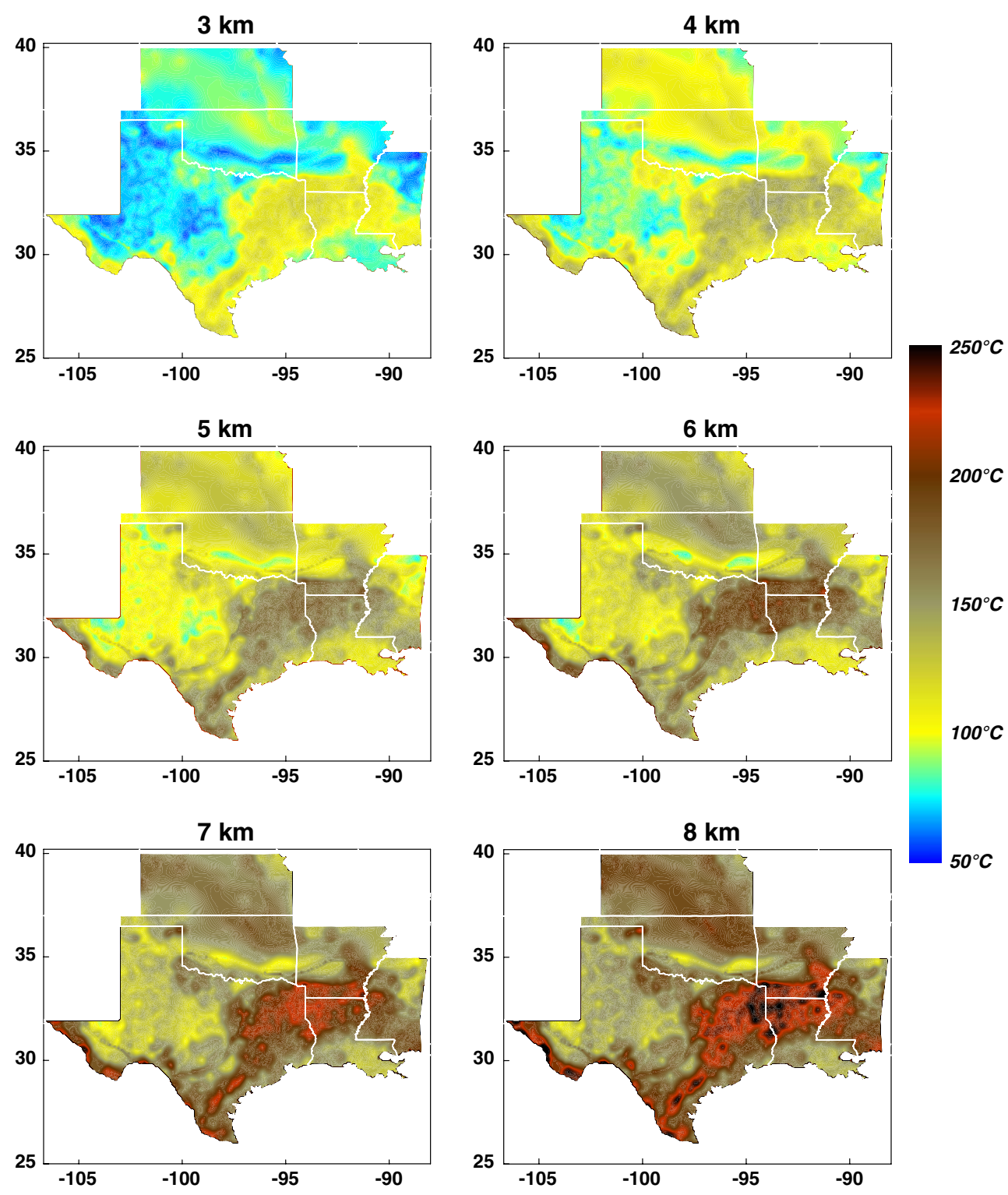

Fig. 9. Temperature at depths of $3-8 \mathrm{~km}$ used in computing the geothermal resource assessment.

The new heat flow data demonstrate that the Ouachita thrust belt divides the area into two thermal provinces. In general lower temperatures are found at the same depth to the west compared to the east. Thus the general resource base above a fixed depth will be higher in the east as compared to the west (excluding the high heat flow regions of the TranPecos) area. The temperatures in the Permian age basins approaches exploitation range (around $150^{\circ} \mathrm{C}$ ) at depths of around $8 \mathrm{~km}$, due to the thick evaporate deposits with very high thermal conductivity and the moderate heat flow. Thermal gradients in those thick evaporate sections could be $<8^{\circ} \mathrm{C} / \mathrm{km}$ (Herrin and Clark, 1956), and only a few deep wells in the Deep Delaware Basin reach such high temperatures. Yet even in these areas the existing wells and infrastructure could lower the cost of the initial investment and geothermal power might be sustainable in so-called coproduced situations (McKenna and others, 2005; Erdlac and Swift, 2006). The only possible conventional geothermal resource west of the Ouachita belt is in the Basin and Range type of structure along the west Texas portion of Rio Grande Rift, where high temperatures were reported 
in a few wells. The thermal information there is insufficient for detailed analysis, and the high temperatures are not verified by deep drilling.

However, east and south of the Ouachita Thrust belt, temperature exceeding $150^{\circ} \mathrm{C}$ in the depths range of 4-8 $\mathrm{km}$ can be found in large areas because of higher heat flow and lower thermal conductivity rocks. Here lies one of the most attractive geothermal resources east of the Rocky Mountains. It extends from the northeast corner of Texas in an easterly direction along the Arkansas/Louisiana border for more than $200 \mathrm{~km}$, up to western Mississippi. The high temperature area is inferred mostly from the AAPG bottom hole temperature (BHT) database which required careful calibration against equilibrium temperature (Blackwell and Richards, 2004), but Mosley and Haynes have temperatures exceeding $120^{\circ}$ at a depth of only $3 \mathrm{~km}$, and in this case the high temperatures are directly documented by equilibrium temperature logs. A second area where the underground temperatures reach exploration range at depths around $6 \mathrm{~km}$ is in the northern Oklahoma and in most of the state of Kansas. In addition to those two areas, there is also a significant geothermal potential in the Gulf Coast sediments. The temperatures in this area normally exceed the temperatures encountered in Oklahoma, and Kansas, though they are not as high as Texas/Louisiana border region. However, the existing geopressured conditions make this area extremely favorable for geothermal development.

The heat in place at a particular depth is computed with the formula:

$$
Q=\rho C_{p} V \Delta T,
$$

where $\rho$ is the rock density (in the calculation was assumed to be $\left.2550 \mathrm{~kg} / \mathrm{m}^{3}\right) ; C_{p}$ is the heat capacity (assumed $1 \mathrm{~kJ} / \mathrm{kg}{ }^{\circ} \mathrm{C}$ ); $V$ is the volume of rock to be cooled, and $\Delta T$ is the temperature difference between the temperature at that depth and a reference temperature (the final temperature of the reservoir). Unlike most geothermal resource studies, where the reference temperature was assumed to be $15^{\circ} \mathrm{C}$, we used a reference temperature of $50^{\circ} \mathrm{C}$. The $15^{\circ} \mathrm{C}$ temperature could be reached if the geothermal development is used for heating, but if the geothermal resource is used for power generation, then the reference temperature should be higher. As the principal target of the geothermal resource is power generation, we decided to use an intermediate temperature value.
Let's consider a cube with dimensions of $1 \mathrm{~km}$ on a side in the most attractive area at the Texas/ Louisiana border, and compute the thermal heat that could be extracted from a depth of $4 \mathrm{~km}$, where temperatures could exceed $150^{\circ} \mathrm{C}$.

$$
\begin{aligned}
& Q=\rho C_{p} V \Delta T \\
& Q=2550 \frac{\mathrm{kg}}{\mathrm{m}^{3}} \cdot 1000 \frac{\mathrm{J}}{\mathrm{kg}^{\circ} \mathrm{C}} \cdot\left(150^{\circ} \mathrm{C}-50^{\circ} \mathrm{C}\right) \\
& Q=0.255 \times 10^{18} \mathrm{~J}
\end{aligned}
$$

This amount of energy could be released only from $1 \mathrm{~km}^{3}$. In typical power plant operations volumes larger than $1 \mathrm{~km}^{3}$ are involved, therefore the total resource will be larger and needs to be multiplied by the area $\left(\right.$ in $\left.\mathrm{km}^{2}\right)$ for which the resource is calculated.

The amount of heat in place is presented as bar plots in Fig. 10 and is calculated for $1 \mathrm{~km}$ slices for each state. Table 3 shows the amount of heat for each temperature interval in the range $100-300^{\circ} \mathrm{C}$, for $50^{\circ} \mathrm{C}$ increments. We have chosen a value of $100^{\circ} \mathrm{C}$ as the base of the resource calculation (the initial temperature in $\Delta T$ ), because it is proven that high flow rates combined with advances in technology could use temperatures below $90^{\circ} \mathrm{C}$ for power generation (Cogswell, 2006).

The maps and the table show a significant geothermal potential between 4 and $6 \mathrm{~km}$ in the south-central United States. By far the largest resource is in Texas, and in parts of this state there is a significant potential at depths that are $<3 \mathrm{~km}$. Of course the large total resource estimate for Texas is in part due to the size of the state. Similar resources exist in Louisiana, Arkansas, and Mississippi. The total resource estimate for each state is in general lower than the resource calculated in the MIT geothermal report (Tester and others, 2006). This is due to the fact that in the present paper, the reference temperature (the final temperature in $\Delta T$ ) is higher than the one used in the report. However, even with our conservative estimates the geothermal resource is huge.

\section{Scenarios for Development}

The first possible type of development would be in high-grade geothermal reservoirs, in west Texas, in faulted structures similar to the ones existing in Nevada. However, the high temperatures are not verified by deep drilling, yet verbal reports of high 

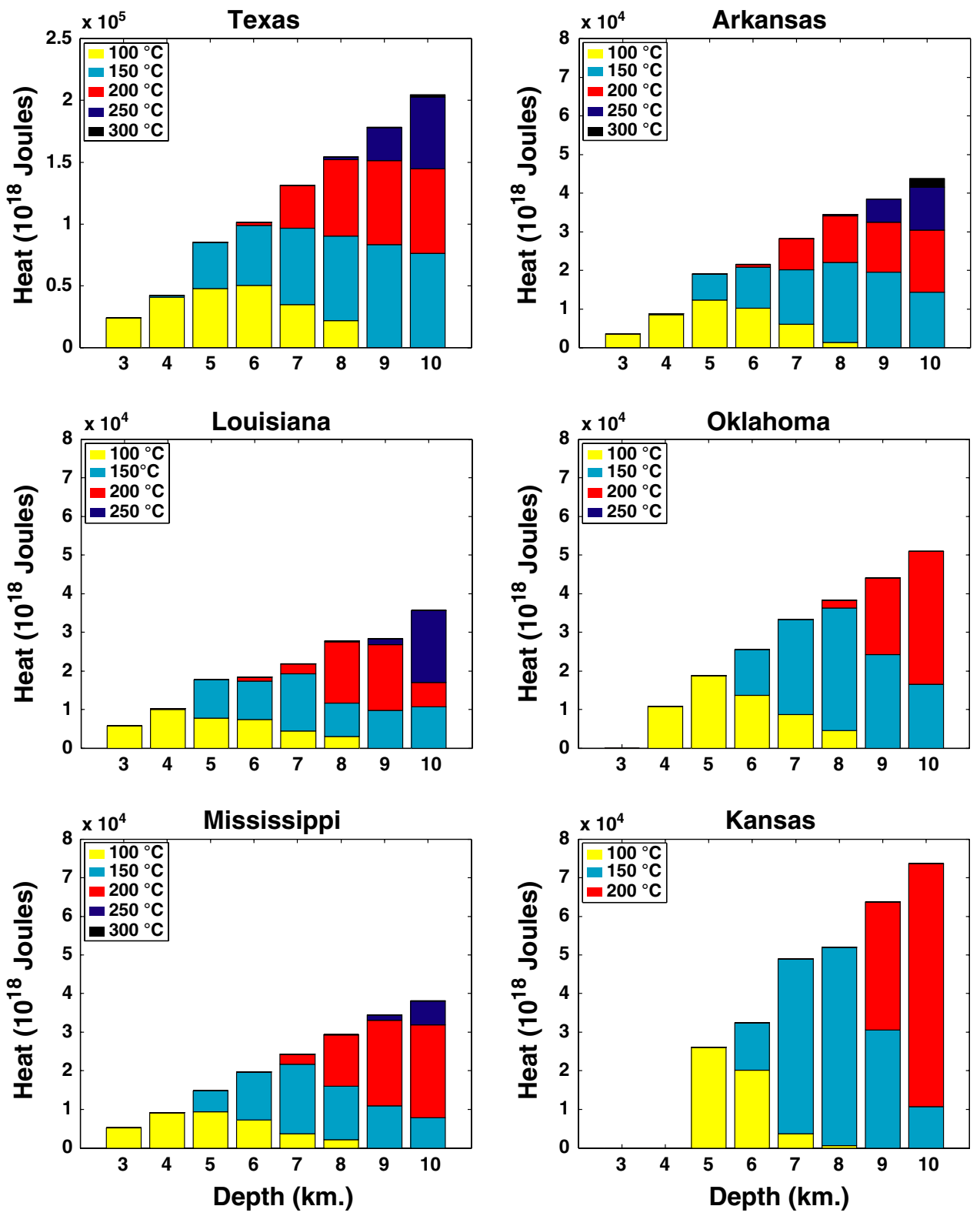

Fig. 10. Available heat for each state in the study area.

temperatures were encountered by the authors from drilling engineers at AAPG meetings. The only setback for such a development would be the remote location and rudimentary infrastructure of the area. This is actually the reason for the scarce drilling and lack of reliable thermal data around the Rio Grande rift in West Texas.

Beside high temperatures, there are other factors that need to be taken into account when evaluating the possible scenarios for development: sediment thickness, rock permeability, crustal stress, and the available volume of fluids.

Figure 11 shows the sedimentary map for the study area and the arrows point to the areas with possible geothermal development. In Kansas and northern part of Oklahoma high temperature areas can be reached at depths below $6 \mathrm{~km}$. A possible setback is that no deep sedimentary basins are present in there, and the possible scenario for development would be in hot dry rock type of 
Table 3. Cumulative heat above $50^{\circ} \mathrm{C}$ to each depth $\left(10^{18} \mathrm{~J}\right)$

\begin{tabular}{|c|c|c|c|c|c|c|c|c|}
\hline & $3 \mathrm{~km}$ & $4 \mathrm{~km}$ & $5 \mathrm{~km}$ & $6 \mathrm{~km}$ & $7 \mathrm{~km}$ & $8 \mathrm{~km}$ & $9 \mathrm{~km}$ & $10 \mathrm{~km}$ \\
\hline \multicolumn{9}{|l|}{ Texas } \\
\hline $100^{\circ} \mathrm{C}$ & 24,246 & 40,939 & 47,596 & 50,194 & 34,753 & 22,029 & 0 & 0 \\
\hline $150^{\circ} \mathrm{C}$ & 14 & 1,147 & 37,521 & 48,788 & 61,697 & 68,170 & 83,462 & 76,176 \\
\hline $200^{\circ} \mathrm{C}$ & - & - & 36 & 2,509 & 34,701 & 61,945 & 68,030 & 68,656 \\
\hline $250^{\circ} \mathrm{C}$ & - & - & - & - & 38 & 2,086 & 26,402 & 57,743 \\
\hline $300^{\circ} \mathrm{C}$ & - & - & - & - & - & - & 278 & 1,929 \\
\hline Total & 24,261 & 42,087 & 85,155 & 101,492 & 131,191 & 154,232 & 178,174 & 204,504 \\
\hline \multicolumn{9}{|c|}{ Louisiana } \\
\hline $100^{\circ} \mathrm{C}$ & 5,756 & 10,017 & 7,767 & 7,400 & 4,434 & 3,081 & - & - \\
\hline $150^{\circ} \mathrm{C}$ & - & 316 & 9,948 & 10,029 & 14,851 & 8,670 & 9,826 & 10,810 \\
\hline $200^{\circ} \mathrm{C}$ & - & - & - & 977 & 2,641 & 15,762 & 17,080 & 6,234 \\
\hline $250^{\circ} \mathrm{C}$ & - & - & - & - & - & 283 & 1,424 & 18,648 \\
\hline $300^{\circ} \mathrm{C}$ & - & - & - & - & - & - & - & - \\
\hline Total & 5,756 & 10,334 & 17,715 & 18,407 & 21,928 & 27,797 & 28,332 & 35,692 \\
\hline \multicolumn{9}{|c|}{ Mississippi } \\
\hline $100^{\circ} \mathrm{C}$ & 5,249 & 9,165 & 9,448 & 7,245 & 3,777 & 2,250 & - & - \\
\hline $150^{\circ} \mathrm{C}$ & - & - & 5,348 & 12,417 & 17,889 & 13,842 & 10,897 & 7,845 \\
\hline $200^{\circ} \mathrm{C}$ & - & - & 31 & 42 & 2,622 & 13,257 & 22,228 & 24,095 \\
\hline $250^{\circ} \mathrm{C}$ & - & - & - & - & 24 & 44 & 1,424 & 6,132 \\
\hline $300^{\circ} \mathrm{C}$ & - & - & - & - & - & - & - & 32 \\
\hline Total & 5,249 & 9,165 & 14,828 & 19,705 & 24,314 & 29,395 & 34,551 & 38,105 \\
\hline \multicolumn{9}{|c|}{ Arkansas } \\
\hline $100^{\circ} \mathrm{C}$ & 3,625 & 8,562 & 12,361 & 10,194 & 6,094 & 1,345 & - & - \\
\hline $150^{\circ} \mathrm{C}$ & - & 174 & 6,730 & 10,665 & 14,043 & 20,677 & 19,578 & 14,368 \\
\hline $200^{\circ} \mathrm{C}$ & - & - & - & 672 & 8,089 & 12,039 & 12,839 & 16,078 \\
\hline $250^{\circ} \mathrm{C}$ & - & - & - & - & - & 456 & 6,102 & 11,089 \\
\hline $300^{\circ} \mathrm{C}$ & - & - & - & - & - & - & - & 2,329 \\
\hline Total & 3,625 & 8,737 & 19,091 & 21,532 & 28,227 & 34,520 & 38,520 & 43,866 \\
\hline \multicolumn{9}{|c|}{ Oklahoma } \\
\hline $100^{\circ} \mathrm{C}$ & 0.765 & 10,825 & 18,835 & 13,721 & 8,748 & 4,588 & - & - \\
\hline $150^{\circ} \mathrm{C}$ & - & - & 18 & 11,782 & 24,638 & 31,695 & 24,270 & 16,569 \\
\hline $200^{\circ} \mathrm{C}$ & - & - & - & - & 3 & 2,085 & 19,876 & 34,407 \\
\hline $250^{\circ} \mathrm{C}$ & - & - & - & - & - & - & - & 17 \\
\hline $300^{\circ} \mathrm{C}$ & - & - & - & - & - & - & - & - \\
\hline Total & 0.765 & 10,825 & 18,854 & 25,503 & 33,390 & 38,369 & 44,147 & 50,995 \\
\hline \multicolumn{9}{|c|}{ Kansas } \\
\hline $100^{\circ} \mathrm{C}$ & - & - & 26,089 & 20,229 & 3,718 & 692 & - & - \\
\hline $150^{\circ} \mathrm{C}$ & - & - & - & 12,221 & 45,242 & 51,171 & 30,569 & 10,642 \\
\hline $200^{\circ} \mathrm{C}$ & - & - & - & - & - & 182 & 33,165 & 63,055 \\
\hline $250^{\circ} \mathrm{C}$ & - & - & - & - & - & - & - & - \\
\hline $300^{\circ} \mathrm{C}$ & - & - & - & - & - & - & - & - \\
\hline Total & - & - & 26,089 & 32,450 & 48,961 & 52,047 & 63,734 & 73,698 \\
\hline
\end{tabular}

environment. Local anomalies hotter than the average could be found, which are beyond of the scope of this study. Yet due to the scale of this study, small scale anomalies both hotter and colder than predicted temperatures could be found, particularly in areas of scarce drilling. However, unlike the present "hot dry rock" developments, the exploration range temperatures are reached at a much greater depth. Oklahoma has deep sedimentary basins, but the temperatures at depth are quite low (Carter, 1993; Carter and others, 1998; Gallardo and Blackwell, 1999), similar to the west Texas Permian basins.
The crustal stress is crucial particularly if the reservoir is stimulated through hydraulic fracturing. The stress in the Gulf Coast is mostly extensional (Zoback and Zoback, 1991), but in general there is not enough information to determine the optimum stress conditions in a geothermal reservoir. Geothermal developments are both in the compressional (Wyborn, de Graaf, and Hann, 2005) and extensional terrains (Duffield and others, 1981; Elsass and others, 1995). Extensional regimes might favor the presence of high permeability rocks and high volumes of fluids, while 


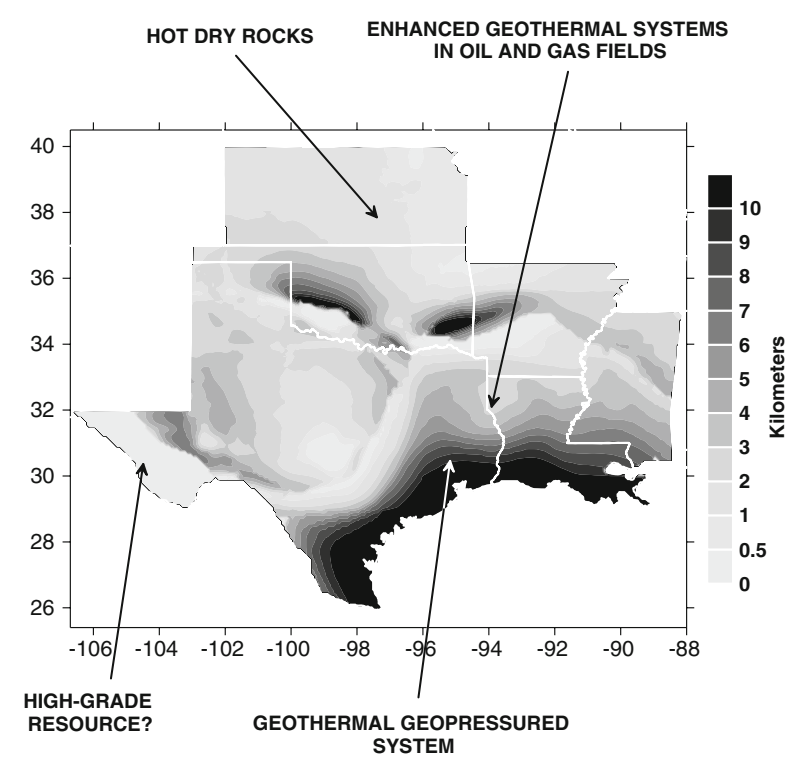

Fig. 11. Map of sediment thickness and possible types of geothermal scenarios in southwestern United States.

compressional stress might favor geopressured conditions.

USGS Circulars 726 and 790 (Papadopulos and others, 1975; Wallace and others, 1979) discuss extensively the resource base for geothermal/ geopressured resources in the Texas and Louisiana Gulf Coast, in an area of more than $145,000 \mathrm{~km}^{2}$. Since those assessments several evaluations have been carried out (e.g., Gregory and others, 1980; John, Maciasz, and Harder, 1998). As part of this process 17 wells of opportunity were studied and a test site was selected for a pilot study at Pleasant Bayou, TX. An existing well was selected and recompleted, an additional injection well was drilled, and the pair were tested for a period of about 5 years. The pilot site was operated as a 1 MW plant between 1989 and 1990 (Campbell and Hattar, 1995). Reservoir analysis (Shook, 1992) indicates that the recovery of pressure was rapid and that the well could have been operated at a rate of $3 \mathrm{MW}$ for at least 10 years. The geother$\mathrm{mal} / \mathrm{geopressured} \mathrm{resource} \mathrm{base} \mathrm{was} \mathrm{estimated} \mathrm{to}$ range from more than 71,000 EJ (Papadopulos and others, 1975) to 170,000 EJ (Wallace and others, 1979) if the volume of dissolved methane is included. The contributions of the methane alone range from 25,000 EJ (Papadopulos and others, 1975) to 63,000 EJ (Wallace and others, 1979).

Currently, there is interest in reopening the Pleasant Bayou well as a test application at the present time. And in January of 2007, the Texas
Land Office leased by competitive bid 11,000 acres of state land for geothermal development along the Gulf Coast.

Given the particularities of the area (large sedimentary thickness, existing oil and gas wells with large amounts of co-produced fluids), the most attractive type of scenario is developing an enhanced geothermal system (EGS) associated with coproduced fluids. To have geothermal electrical power production you need high fluid flow rates at temperature in excess of $100^{\circ} \mathrm{C}$. For large areas in Texas and Louisiana, temperatures reach $120^{\circ} \mathrm{C}$ at a depth of only $3 \mathrm{~km}$, and because this was verified by drilling, the potential for geothermal resources is clearly valid. The fluid flow rates required by a geothermal development are on the order of 500-1,000 gallons per minute (GPM) per MW (depending on the temperature), and these rates could be easily sustained in parts of Texas, Oklahoma and Louisiana. Texas alone produces more than 12 billion barrels of water per year, and in the area of interest northeastern Texas and southwestern Arkansas 50,000 barrels/day of fluid are produced and paid for (in terms of pumping and disposal costs) by existing oil and gas operations. In many cases, this water has already passed through a hydrocarbon separation station and collecting the fluid and passing it through a binary system power plant before disposal could be a straightforward process.

The existing field conditions of the area suggest the available power could be extracted with minimum additional investment. Many of the wells were already drilled, and they have high BHTs in the production range. In many cases the reservoirs are already stimulated by hydraulic fracturing, sustained high flowrates are present, and the infrastructure (power lines, pipes, and roads) is already in place. Therefore, the cost of drilling and producing water is already covered by the existing oil operations. The main additional investment would be building the power plant.

A rule of thumb is that the temperature of the cooled part of the EGS will recover to about $90 \%$ after a rest period of the about three times the period required to lower it to the point where power production ceased. So development in a larger area could allow cycling of the field and over 100 years of operation (Pritchett, 1998). In areas where large numbers of wells are present, such as northeast Texas, southwest Arkansas, northwest Louisiana and parts of Mississippi, this type of scenario might be very practical and economical. Therefore in this case at least, the geothermal resource is sustainable. 


\section{OPEN ACCESS}

This article is distributed under the terms of the Creative Commons Attribution Noncommercial License which permits any noncommercial use, distribution, and reproduction in any medium, provided the original author(s) and source are credited.

\section{REFERENCES}

Beall, A. O. Jr., 1964, Stratigraphy of the Taylor formation (upper cretaceous), east-central Texas: Baylor University, Baylor Geological Studies, Bull. v. 6, 31 p.

Beardsmore, G. R., and Cull, J. P., 2001, Crustal heat flow. A guide to measurement and modeling: Cambridge University Press, New York, 332 p. ISBN-10:0521797039.

Blackwell, D. D., and Spafford, R. E., 1987, Experimental methods in continental heat flow, in Sammis, C. G., and Henyey, T. L., eds., Geophysics Field Measurements: Methods of Experimental Physics, v. 24, part B: Academic Press, New York, p. 189-226.

Blackwell, D. D., and Steele, J. L., 1989, Thermal conductivity of sedimentary rocks: measurement and significance, in Naeser, N. D., and McCulloh, T. H., eds., Thermal History of Sedimentary Basins: Methods and Case Histories: SpringerVerlag, New York, p. 13-36.

Blackwell, D. D., Beardsmore, G. R., Nishimori, R. K., and McMullen, R. J., 1999, High resolution temperature logs in a petroleum setting: examples and applications, in Forster, A., and Merriam, D. eds., Geothermics in Basin Analysis: Kluwer Academic/Plenum Publisher, p. 1-33.

Blackwell, D. D., and Richards M. C., 2004, Geothermal map of North America: Am. Assoc. Petrol. Geol., Scale 1:6,500,000.

Blackwell, D. D., Negraru, P. T., and Richards, M.C., 2007, Assessment of the enhanced geothermal system resource base of the United States: Nat. Resour. Res., v. 15, no. 4, p. 283-308. doi:10.1007/s11053-007-9028-7.

Brigaud, F., Chapman, D. S., and Le Douran, S., 1990, Estimating thermal conductivity in sedimentary basins using lithologic data and geophysical well logs: Am. Assoc. Petrol. Geol. Bull., v. 74, no. 9, p. 1459-1477.

Bullard, E. C., 1939, Heat flow in South Africa. Proc. R. Soc. Lond. A, v. 173, no. 955, p. 474-502. doi:10.1098/rspa.1939. 0159.

Campbell, R. G., and Hattar, M. M., 1990, Operating results from a hybrid cycle power plant on a geopressured well: Geotherm. Resour. Council Trans., v. 14, p. 521-530.

Carter, L. S., 1993, Heat flow and thermal history in the Anadarko basin, Oklahoma: M.S. thesis, Southern Methodist University, $168 \mathrm{p}$.

Carter, L. S., Kelley, S. A., Blackwell, D. D., and Naeser, N. D., 1998, Heat flow and thermal history of the Anadarko basin, Oklahoma: Am. Assoc. Petrol. Geol. Bull., v. 82, no. 2, p. 291-316.

Cogswell, F. J., 2006, An ORC power plant operating on a lowtemperature $\left(165^{\circ} \mathrm{F}\right)$ geothermal source: Geotherm. Resour. Council Trans., v. 30, p. 729-732.

Demongodin, L., Pinoteau, B., Vasseur, G., and Gable, R., 1991, Thermal conductivity and well logs: a case study in the Paris basin: Geophys. J. Int., v. 105, no. 3, p. 675-691. doi:10.1111/ j.1365-246X.1991.tb00805.x.

Doveton, J. H., Forster, A., and Merriam D. F., 1997, Predicting thermal conductivity from petrophysical logs: a mid-continent
Paleozoic case study, Proc. of IAMG '97. The Third Annual Conference of the International Association for Mathematical Geology.

Duffield, R. B., Nunz, G. J., Smith, M. C., and Wilson, M. G., 1981, "Hot Dry Rock", geothermal energy development program: Annual report FY80, Los Alamos National Laboratory Report, LA-8855-HDR, 211 p.

Elsass, P., Aquilina, L., Beauce, A., Benderitter, Y., Fabriol, H., Genter, A., and Pauwels, H., 1995, Deep structures of the Soultz-Sous-Forets HDR Site (Alsace France), Proc. of the World Geothermal Congress, Florence, Italy, p. 2643-2647.

Erdlac, R. J., and Swift, D. B., 2006, Deep permeable strata geothermal energy (DPSGE): tapping giant reservoirs within deep sedimentary basins-an example from Permian Basin carbonate strata: Geotherm. Resour. Council Trans., v. 28, p. 327-331.

Flawn, P.T., Goldstein, A. Jr., King, P. B., and Weaver, C. E., 1961, The Ouachita system: Bureau of economic geology: University of Texas at Austin, Publication no. 6120, 401 p.

Gallardo, J., and Blackwell, D. D., 1999, Thermal structure of the Anadarko basin: Am. Assoc. Petrol. Geol. Bull., v. 83, no. 2, p. 333-361.

Gosnold, W. D., Todhunter, P. E., and Schmidt, W., 1997, The borehole temperature record of climate warming in the midcontinent of North America: Global Planet. Change, v. 15, p. 33-45. doi:10.1016/S0921-8181(97)00002-7.

Gregory, A. R., Dodge, M. M., Posey, J. S., and Morton, R. A., 1980, Volume and accessibility of entrained (solution) methane in deep geopressured reservoirs - Tertiary formations of the Texas Gulf Coast: U.S. DOE final report DOE/ ET/11397-1, 361 p.

Gretener, P. E., 1981, Geothermics: Using temperature in hydrocarbon exploration: AAPG Education Course Note Series $17,170 \mathrm{p}$.

Gustavson, T. C., Bassett R. L., Finley, R. J., Goldstein, A. G., Handford, C. R., McGowen, J. H., Presley, M. W., Baumgardner, R. W., Bentley, M. E., Dutton, S. P., Griffin, J. A., Hoadley, A. D, Howard, R. C., McGookey, D. A., McGillis, K. A., Palmer, D. P., Ramondetta, P. J., Roedder, E., Simpkins, W. W., and Wiggins, W. D., 1981, Geology and geohydrology of the Palo Duro basin, Texas Panhandle: A report on the progress of nuclear waste feasibility studies: Bureau of Economic Geology, University of Texas at Austin, DOE/ET/46615-T2, $181 \mathrm{p}$.

Herrin, E. T., and Clark, S. P., 1956, Heat flow in west Texas and eastern New Mexico: Geophysics, v. 21, no. 4, p. 1087-1099. doi:10.1190/1.1438306.

John, C. J., Maciasz, G., and Harder, B. J., 1998, Gulf coast geopressured-geothermal summary report compilation: Report DOE/ID/13366-T1-Vol. I-V.

McKenna, J., Blackwell, D. D., Moyes, C., and Patterson, P. D., 2005, Geothermal electric power supply possible from Gulf coast, midcontinent oil field waters. Oil Gas J., Sept. 5, v. 103, no. 33 , p. 34-40.

Merkel, R. H., Maccary, L. M., and Chico, R. S., 1976, Computer techniques applied to formation evaluation: Log Anal., v. 17, no. 3, p. 3-10.

Olivier, W. B., 1971, Depositional systems in the Woodbine formation (upper Cretaceous), northeast Texas: Bureau of Economic Geology, University of Texas at Austin, Report of investigation no. 73, $28 \mathrm{p}$.

Owen, M. T. (1979) The Paluxy sand in the north-central Texas: Baylor University, Baylor Geological Studies, Bull., no. 36,36 p.

Papadopulos, S. S., Wallace, R. H. Jr., Wesselman, J. B., and Taylor, R. E., 1975, Assessment of onshore geopressuredgeothermal resources in the northern gulf of Mexico basin, Assesment of Geothermal Resources of the United States-1975; U.S. Geol. Survey Circ., v. 726, p. 125-140. 
Plummer, F. B., and Sargent, E. C., 1931, Underground waters and subsurface temperatures of the Woodbine sand in northeast Texas: Bureau of Economic Geology, The University of Texas Bull. no. 3138, October, 178 p.

Press, W. H., Teukolsky, S. A., Vetterling, W. T., and Flannery, B. P., 1992, Numerical recipies in Fortran. The art of scientific computing: Cambridge University Press, 256 p. ISBN 10:0521437210.

Pritchett, J. W., 1998, Modeling post-abandonment electrical capacity recovery for a two phase geothermal reservoir: Geotherm. Resour. Council Trans., v. 22, p. 521-528.

Shook, G. M., 1992, An integrated approach to reservoir engineering at Pleasant Bayou geopressured-geothermal reservoir: DOE technical report EGG-EP-10557, 48 p.

Surles, M. A. Jr., 1987, Stratigraphy of the Eagle Ford Group (Upper Cretaceous) and its source rock potential in the East Texas Basin: Baylor University, Baylor Geological Studies, Bull. no. 45, 57 p.

Tester, J. W., Anderson, B., Batchelor, A., Blackwell, D. D., DiPippo, R., Drake, E., Garnish, J., Livesay, B., Moore,
M. C., Nichols, K., Petty, S., Toksoz, N., Veatch, R., Augustine, C., Baria, R., Murphy, E., Negraru, P. T., and Richards, M., 2006, The future of geothermal energy: Impact of enhanced geothermal systems (EGS) on the United States in the 21st century. Massachusetts Institute of Technology, DOE contract DE-AC07-05ID14517 final report, $209 \mathrm{p}$.

Wallace, Jr., R. H., Kraemer, T. F., Taylor, R. E., and Wesselman, J. B., 1979, Assessment of geothermal resources of the United States-1978, in Muffler, L. J. P., ed., Assessment of Geopressured-Geothermal Resources in the Northern Gulf of Mexico basin: U. S. Geol. Survey Circular 790.

Wyborn, D., de Graaf, L., and Hann, S., 2005, Enhanced geothermal development in the Cooper Basin, South Australia: Geotherm. Resour. Council Trans., v. 29, p. 151-156.

Zoback, M. D., and Zoback, M. L., 1991, Tectonic stress field of North America and relative plate motions, in Slemmons, D. B., Engdahl, E. R., Zoback, M. D., and Blackwell, D. D. eds., Neotectonics of North America, Geol. Soc. America Decade Map Volume, p. 339-366. 